\title{
The Poet at the Teacher's Desk: W.H. Auden on Education, Democracy and Humanity
}

\section{Ladislav Vít}

In the 193os W.H. Auden taught at several public schools in Britain while simultaneously embarking on his poetic career. Later in life, he lectured at various educational institutions and returned to Oxford, his alma mater, in the 1950s as Oxford Professor of Poetry. His experience of teaching allowed Auden to reflect upon the pitfalls of Britain's interwar educational system and its social function. Therefore, this article diverts attention from the prevailing scholarly focus on Auden's poetry to his critical prose in order to examine the poet's concerns about the content, purpose and role of education in society, his views on the structure of the educational system and disquiet about the tension between the utilitarian and humanistic dimensions of the educational process. At a more general level, the paper points out the relation that Auden maintained existed between education, democracy, art and the "crystallizing" power of poetry.

Keywords

Wystan Hugh Auden; education; humanity; democracy; Fascism

In 1925, after five years of boarding at Gresham's School in Holt, Norfolk, W.H. Auden went to Christ Church, Oxford, to read natural sciences. He switched to politics, philosophy and economics in 1926, before switching to English a few months later. After graduating Auden spent a year in Berlin amidst his coterie and returned to England in July 1929, which ended what he called his "rentier" existence - a period of economic dependence on his parents (1939a: 417). With no income and only a handful of poems handprinted by Stephen Spender in 1929, Auden came home in search of an occupation. He wrote to his friend Naomi Mitchison and asked if she knew about "anything from nursing to burglary" (Mitchison 117). Auden's teaching career was soon to begin. Mitchison let Auden tutor her son Murdoch, who would later become a prominent biologist and Professor of Zoology at the University of Edinburgh. Following this, in April 1930, Auden succeeded his 
friend Cecil Day-Lewis at Larchfield School (later Academy) in Helensburgh, Dumbartonshire, where he taught until 1932. In the autumn of the same year, he began teaching at Downs School, Colwall, Herefordshire, where he stayed for the following three years, until 1935. Although by the end of the decade, Auden had become a full-time poet, he did not give up on teaching even after settling in New York in 1939. He occupied himself with lectures and lecture tours at various educational institutions - secondary schools, colleges and universities on both sides of the Atlantic. The most successful series was delivered at Swarthmore College (1942-1945), and resulted in a collection of published lectures on Shakespeare. The highlight of Auden's pedagogical career, however, came in 1956 . His educational journey came full circle when the third-class Oxford graduate returned to his alma mater to become Professor of Poetry. In the thirty years between graduation and professorship, Auden had taught and written an impressive number of essays, book reviews and poems dealing with pedagogical matters as their prime or marginal topic. Whatever the form, the rigour and zest of their arguments reveal that the teaching experience allowed Auden to form insightful opinions on the social function of education and its flaws.

W.H. Auden's interwar opinions on education derived in part from this extensive personal experience of educational institutions and in part from his political beliefs of the 1930s. In 1937, T.C. Worsley and Auden asked: "Educational theory begins when society has become differentiated, when different classes are living so differently, and doing such different things that the question arises: 'What shall we teach and to whom?"' (408). Their attempt to provide an answer reveals insistence on a twofold purpose of education, in which Auden looked for a balance between personal and communal aspects. "All education", he argued, "is a preparation for life. It must teach people how to do the things which will keep them alive, agriculture, hunting, fighting and what not; and it must teach them how to live together, the laws, customs and beliefs of the community" (408). Clearly, Auden demanded that education should train the professional skills appropriate for particular social strata in order for everyone, regardless of class, to be able to provide for their individual existential needs. In this aspect, as he often asserted, education should deliver specific vocational guidance by helping individuals find their talents and then assist their full development. Second, Auden's statement suggests that he expected education to cultivate general civic skills allowing citizens across the social spectrum to prepare for responsible and active participation in the organization of their communities. 
As implied in the citation above, in his assessment of the importance and quality of both aspects of education, Auden takes into account the type of social environment in which it takes place because he insisted on a close practical relation between education and society. It is more than evident, for instance, that the increasing pressure Nazi Germany started to exert on democratic states in the 1930 encouraged Auden to shift his main focus from the vocational and utilitarian towards general education. When defining the purpose of education in democracy, he contrasted it with a totalitarian state. In a society ruled by Fascism, Auden argued in 1938 and again five years later, the practicality of education lies primarily in nurturing and strengthening belief in the ruling system and in training military and vocational skills. Education in democracy, on the contrary, should primarily cultivate general civic skills rather than indoctrinating and strengthening political beliefs or training specific professional skills embedding individuals in their particular professional niche (1943: 179; 1938c: 475).

As the 1930s progressed towards the war, Auden started to clarify his understanding of general civic skills, as well as his appeal for their cultivation. He viewed them as a set of skills allowing citizens to actively, rationally and voluntarily participate in the sustenance and improvement of their social environment. The rationale behind Auden's emphasis on the general civic skills is rooted in his view of democracy as a political system. First, he was convinced that the belief in democracy is a belief in a social environment that can be changed for the better by means of the contributions of all its members (1938d: 481). Democracy, he argued, is a polity "where every citizen is expected to be able to take part in political life (using 'political' in its widest sense)" (1938c: 475). Auden's understanding of the word "political" was very broad. In 1939 he wrote that a "politician" is anyone who "wants to organize the lives of others", adding that when in company, all people are politicians (1939: 412, 416).

This reflects Auden's general interwar trust that true democratic societies consist of individuals who participate in public life because they are guided by a relentless desire to improve the living conditions of their community. In this connection, he often discussed two contrasting types of persons - the "average man" and the "highbrow", defining them in terms of a contrasting approach to experience. The former was for him "[a] person who is passive towards experience: his knowledge is limited to what comes to him automatically through immediate personal experience". The latter, on the contrary, is an individual who "seek[s] to extend their experience beyond the immediately 
given", someone "who is not passive to his experience but who tries to organise, explain and alter it, someone in fact, who tries to influence his history" (1939a: 413, 1933b: 37). In Auden's opinion, all citizens in a genuine democracy should be such "highbrows" actively engaging in civic issues.

In response to the escalating threat that German Nazism posed to European democracies in the 193os, Auden intensified his plea to the British public, regardless of class, to become such active citizens involved in public matters. This engagement, Auden stressed, was to be voluntary. An essential part of his idea of citizenship and general civic skills was the development of the individual willingness of all the members of a democratic community to influence and improve its welfare. "Democracy", he wrote in his Foreword to Poet Venturers in 1938, "cannot be genuine unless each of us, in his or her sphere, is prepared to serve it with heart and head; at the same time Democracy cannot demand such service; it has to be given of our free will" (1938e: 471). He viewed such a commitment as an integral component of his idea of democracy and thus as the basic civic duty of every member of a democratic polity. This is why several essays from the period deem placid stolidity and the isolationist withdrawal of individuals from public matters unacceptable. In 1938, for example, Auden wrote in the heat of the appeasement policy that

[i]n periods of steady evolution, it is possible for the common man to pursue his private life without bothering his head very much over the principles and assumptions by which he lives, and to leave politics in the hands of professionals. But ours is not such an age. It is idle to lament that the world is becoming divided into hostile ideological camps; the division is a fact. No policy of isolation is possible. Democracy, liberty, justice, and reason are being seriously threatened and, in many parts of the world, destroyed. (1938d: 486)

Auden's insistence on the active and voluntary participation of each member of a community in its public affairs reflects his belief that this very attitude is what makes democracy a potent antidote to dictatorial regimes which suppress such qualities in their citizens. His position issues from the social consciousness of the generation of the 1930s with whose ideals he is associated. In this context, Valentine Cunningham explained the tendency of interwar intellectuals to participate in public issues and lean towards the left of the political spectrum in terms of an attempt to "go over" to the masses and assuage their middle-class "crise de conscience" (211-240). Additionally, in 
terms of contemporary terminology within political theory, Auden's stress on forming a civic and participant community falls within the "rationalityactivist" model of political culture, as defined, for instance, by Gabriel A. Almond and Sidney Verba: "[ $\mathrm{t}]$ he democratic citizen is expected to be active in politics and to be involved. Furthermore, he is supposed to be rational in his approach to politics, guided by reason, not by emotion. He is supposed to be well informed and to make decisions" (31).

Convinced of the crucial role that education plays in the formation of any society, what grew alongside Auden's appeals to Britain's general public was his reliance on teachers. He believed that they should be instrumental in "hatching" citizens eager to change and improve their social environment. As early as in 1934 he expressed his view of teachers as agents of social change lucidly when he wrote that "[ $\mathrm{t}]$ he progress of the realization of values is like that of scientific inventions; it renders obsolete its predecessors. A state has to train its youth not only to be its good citizens, but to change it, i.e., to destroy its present existence. Educationalists must always be revolutionaries" (1934b: 66). Perhaps because of their exceptional potential to have an immediate impact on future generations, Auden included teachers among his prime examples of "politicians" capable of influencing the lives of others and among "highbrows" (1938d: 486) conscious of experience. Their "first job now", he argued, "is to take part in political action" (1939b: 466). To be such a teacher was, for Auden, to strive to nurture citizens who relentlessly desire to lead what he called "an intelligent political life", consisting of an effort to surpass the status quo of their social environment.

Auden was convinced that to turn average "passive men" into "politically" active citizens requires the full focus of teachers on general education and civic skills. Through the 1930s he repeatedly claimed that they should primarily aim to help pupils develop "character", "personality" and "citizenship" (Auden and Worsley 393). It transpires from Auden's prose that the first two elements of this triad were for him the prerequisites for the third and they issued from pupils' development of critical awareness. In fact, this conviction became the key ingredient in his idea of citizenship and education in democracy, which cannot "survive unless a very large percentage of its citizens take an interest in what are commonly called things of the mind, read widely, think dispassionately" (Auden and Worsley 418). Auden repeatedly suggested that the ability to participate in public issues derives from the citizens' capacity to form an unflustered opinion allowing them to formulate an independent judgement and make a rational choice. "Education in a democracy must", 
Auden was persuading the readers of The Nation in 1938, "develop the reason and the consciousness of every individual, whatever his job, to a point where he can for himself distinguish good from bad, and truth from falsehood" (1938d: 482). That this be nurtured and cherished throughout the social hierarchy was for him a basic precondition for the sustenance of democracy: "[u]nless all the members of a community are educated to the point where they can make a rational choice, democracy is a sham" (1939b: 466, emphasis added).

Auden's insistent tone in these citations issues from the context in which he wrote his essays. For him critical awareness and judgement were the best means of opposing control and malleability, thus, tools for protecting freedom and democracy against Nazism or other forms of totalitarian, egalitarian and oppressive systems. Hence, teachers, Auden claimed, should refrain from authoritatively instilling knowledge. On the contrary, they should take all possible care to be guides assisting the development of pupils' selfconsciousness and critical independence (1934a: 6o-61). Only then would learners succeed in developing the individuality and opinion necessary for their fruitful democratic citizenship.

Auden's insistence on the applicability of education to the social environment and his belief in the role of general education in orienting pupils towards active participation in communal issues gave him plenty of reasons for discontent with interwar education in Britain. His first-hand experience, in combination with his socialist worldview, made him deem the school system insensible to the basic principles of a democratic social environment. Auden was very consistent in his critique of the shortcomings of the British educational system. At the most general level, he criticized the impracticality and detachedness from the social environment of all levels of education. Assessing the purpose and flaws of secondary schools, for instance, Auden and Worsley promoted the importance of praxis: "What one learns, one learns by practice and by personal apprenticeship to those who are good at their profession" (416). Auden warned of the danger of a dominant tendency towards the instillment of theoretical, abstract and inapplicable knowledge. "Our education is too bookish", he wrote in 1933 while teaching at Colwall; "[...] a boy in school remains divorced from the means of production, from livelihood" (1933b: 38). Auden was equally critical of tertiary education. He blamed universities for instilling passivity and detachedness from social issues. Well beyond the 193 os he made disrespectful remarks about the socially inconsequential focus of academic research. In 1947, for example, he belittled scholars for counting John Betjeman's poetic references to a bicycle (1947: 304). In "Doggerel by 
a Senior Citizen" (1969) he scorned doctoral students when he wrote that "Nor are those Ph.D's my kith, / Who dig the symbol and the myth" (1976: 639). ${ }^{1}$

The grumpy tone of these lines of verse, however, does not merely reflect the 1960 s seniority implied in the title of the poem. The same timbre already resonates through Auden's interwar writing. As the situation on the Continent in the 193os spiralled towards war, his criticism of educational institutions for their lack of interest in the social situation escalated to unprecedented levels. Auden's comments became derogatory and sarcastic, revealing frustration, as in the phrase "squalid shadow of academy", which he used in a 1935 poem "August for the people and their favourite islands", where he blames universities for lackadaisical ivory-tower detachedness from social problems and rising radicalism (1988: 157). ${ }^{2}$ The interwar situation, in other words, encouraged Auden to eclipse his critique of the theoretical quality of vocational schooling with a pronounced attention to the neglect of general civic skills. In 1939, for instance, he asserted bitterly that "[n] one of us who have anything to do with education $[\ldots]$ can help feeling that we have had a certain success in giving people educational training and enabling them to do certain kinds of tricks and certain kinds of jobs, but that so far as making citizens or influencing the world in any way is concerned we have utterly failed" (1939b: 464). No other essay from the period expresses his conviction about the predominance of vocational over general civilian aspects of education more clearly.

As shown above, the ability to form an independent opinion was, for him, a crucial aspect of democracy. However, instead of providing stimuli for the development of critical awareness, education, Auden argued, instilled mere factual and theoretical knowledge. "The predominance of the factual over the humanistic in education persists", Auden and Worsley wrote in 1937 (393). The failure to nurture independent opinion, personality and social commitment meant for him that education produced passive and self-absorbed citizens. This diminished their ability and willingness to participate in public matters and, by extension, in constructing a democratic social environment which would withstand the threats of rising dictatorship.

Auden came to the conclusion that schools displayed an insufficient emphasis on what he considered to be the basic tenets of humanity and democracy. He criticized the British educational authorities for maintaining an educational system that neglected the cultivation in pupils of general civic skills and social cohesion. Instead, in his view, it encouraged detachedness through training self-interest and blindness to the needs of others. In 1939, he put it thus: "our education is not so far bringing people towards a democratic 
state. On the contrary, it is encouraging them to become more assertive and less interested in the mass of the people; there is a scramble to get to the top, because people must escape as far as they can from economic pressure" (1939b: 465). He criticized parents, for instance, for encouraging this tendency by expecting education to provide their children with the means for upward social mobility, financial security and higher social status, hence individual rather than communal benefits. Together with Worsley, Auden blamed them for rarely desiring education "to produce civilized and cultured people with a reverence for life and awareness of values" (395).

Auden tried to understand the state of the educational system in larger social contexts mainly because he was convinced that education always reflects the norms of the society which creates it (Auden and Worsley 407). A part of his affiliation with the 1930 generation of intellectuals suffering from a crise de conscience was that Auden found the culprit behind the disquieting situation in education in the size of the society and within his own class. He was convinced that self-interest, lack of critical awareness and the neglect of cohesion in education derived from the fact that Britain was a large modern Liberal-Democratic state whose educational principles and social norms were determined, implemented and maintained by the middle class as its ruling stratum.

The gravamen of Auden's 1930s prose is that a conscious engagement of an individual in the construction of their social milieu was decimated through the emergence of large collectivities and mass production. Unlike small-sized pre-industrial "communities" characterized by homogeneity and the unity of interest and comradeship of their members (1932: 18), Auden saw Britain in terms of a modern "society" made up of a large body of people whose number debars common interest, communal experience and homogeneity. The size and organization of such "crowds", as he disparagingly called them, entails ignorance of the basic attributes of humanity: the individuality of its members, their critical consciousness, creativity, communal belongingness and the will to participate in shaping the habitat. Moreover, Auden claimed that LiberalDemocratic policy in general is characterised by the instigation of "social inequality, class war, lack of social conscience, lack of social cohesion, lack of sociality" (1939b: 464). He further argued that the size, lack of common interest, heterogeneity and differentiation characterizing modern "crowd" societies cause social injustice and a feeling of individual powerlessness to influence the public. Consequently, he held, in such societies self-interest and selfishness supersede the commitment to public issues and individuals withdraw 
from engagement in communal matters (1967: 28). Such atomization and social alienation cause passivity, self-absorption, loneliness and the reluctance of individuals to manifest their will to participate in the shaping of the communal habitat. In assessing the nature of large modern collectivities, Auden quoted from Melville's Moby Dick to support his conviction: "If a community [...] dissolves, the societies, which remain [...] must, left to themselves, grow more and more mechanical. And such real individuals as are left must become Ishmaels, 'isolatoes, not acknowledging the common continent of men, but each isolatoe living in a separate continent of his own" (1967: 34).

Auden's use of the term "mechanical" reveals, even a decade after repudiating socialist politics, his notional indebtedness to Karl Marx's idea of "Reification" - the act of turning people into "mechanical" thoughtless objects in the process of planned manufacture. He applied such views to the social sphere and in so doing showed the readiness of his generation to highlight the connection between the middle class and the interwar situation. ${ }^{3}$ He claimed that the critical awareness and self-consciousness of an individual are as undesirable in the organization of mechanical production as in the organization of large capitalist structures. The sustenance of a large social group by the middle classes entails the suppression of critical awareness, resulting in the transformation of people into depersonalized "behaviourist automatons" (1933a: 31) and mechanistic "instruments of their particular function" (1967: 28-29) within such an established system. To Auden the suppression and neglect of critical awareness had led in Britain, as in any capitalist society, to the florescence of uncritical, complacent and gullible individuals: "The commonest ivory tower", he bitterly asserted in 1939, "is that of the average man, the state of passivity towards experience" (1939a: 413).

Auden's critical attitude to British interwar education and large capitalist collectivities derives from a conviction about a shared ill. He held that their common neglect of self-understanding, critical awareness and participation in communal issues defies some of the essential attributes of humanity and democracy as its prime manifestation.

Humans, in Auden's opinion, have an inherent predilection for a communal life, through which individuals acquire goodness on experiential bases. In one of his attempts to censure the tenets of romanticism, Auden argued against the emphasis of romantic writers on isolation and the idea of inborn virtues. "Man has always been a social animal living in communities", he asserted in The Nation in 1938 and added that "[t]he individual in vacuo is an intellectual abstraction. The individual is the product of social life; without it, he could 
be no more than a bundle of unconditioned reflexes. Men are born neither free nor good" (1938d: 479). Another important part of Auden's reflections on the distinctive aspects of humanity was his view of the relations between different species and the environment. "The history of life on this planet", Auden wrote in December 1938, "is the history of the ways in which life has gained control over and freedom within its environment. Organisms may either adapt themselves to a particular environment [...] or develop the means to change their environment". In order to explicate his claim, Auden revealed a traditional respect for a hierarchy with man situated at its apex. He argued that organisms below the human level adapt by means of "structural biological changes", while only man continues its evolution through the use of "conscious intelligence" (1938d: 478). The argument is that it allows humans to understand the laws of nature and society. In consequence, rather than adapt to the environment, man has an exclusive power to control it and, using its will, continuously change it: "[man] is the only animal capable of using his intelligence and making choices; the only animal whose society can develop from one form into another" (1939b: 463). In view of the above, it is clear that Auden understood democracy as the most characteristic manifestation of humanity. Unlike dictatorial regimes, it also rested on the idea of a continuous change of the environment attained through the capacity and willingness of its members to make rational choices for the sake of the community. "Democracy", he argued in 1938 ,

surely believes that moral good, the possibility of moral choice, is not only for the few favoured people, but for the vast majority of ordinary decent men and women. [...] A great many people believe that those who are capable of making a moral choice are few, and that the rest of mankind must be disciplined by propaganda and coercion of one kind or another so that they shall become good. This is not the democratic point of view. (1939b: 463-464)

Hence, Auden's bitterness about the failure of the interwar educational system to nurture civic skills was in fact bitterness about its failure to cherish humanity. For this reason, he was ready to liken the British school system to undemocratic dictatorial regimes. In 1934, for example, he put it thus: "The best reason I have for opposing Fascism is that at school I lived in a Fascist state" (1934a: 59). In his view, Fascism and education in Britain coalesced in suppressing egalitarianism, personality and the critical mind. Instead, he 
would claim, interwar education and Fascism both had a dehumanizing effect by means of instilling hierarchy, classism, passive obedience and strategies that obliterated the development of the individual will and critical mind. A democratic life is, Auden concluded, "a life of love and affection among ordinary happy people, a life which capitalism, specialisation, and overacademic education made and are still making extremely difficult" (1938a: 468). Auden's pessimism concerning the infinitesimal amount of attention paid in British schools to general civic skills grew in direct proportion to the growing threat of Nazism. As the situation in the 1930 s worsened and the threat of Nazism grew more imminent, Auden started to think of educational authorities in terms of active participants in centrally imposed dehumanizing processes producing unthinking average men easy to control:

The last hundred years have seen an immense advance not only in knowledge, but also in the technique of spreading and instilling it. [...] Whoever possesses the instrument of knowledge, the Press, the Wireless, and the Ministry of Education, is the dictator of the country; [...] it becomes increasingly difficult to overthrow a bad one because imitating our voice, he makes us believe that he does not exist. (1933a: 29)

Auden gradually realized that his wish for the educational system to change was vain. Towards the end of the decade he started to fully pronounce what he had already anticipated in 1934, when he wrote that education reflects the society which had created it, and hence it "succeeds social revolution, not precedes" (1933a: 30). Therefore, Auden and Worsley argued, any attempt to change education with the intention of changing the social system is futile:

Education can never be more effective than the structure of society as a whole will let it, and the teacher who imagines that you can effectively change education without first changing society will end either by throwing the whole contraption overboard in despair like D.H. Lawrence, or by deceiving himself with a lot of gas about Service like Dr Norwood. (413)

Auden's accumulated pessimism, stemming from his failure to find in education an ally for nurturing humanity and democracy through dwelling upon general civic skills, intensified his readiness to consider alternative means. In his recent study examining the position of the humanities within contemporary education and society, Geoffrey Galt Harpham claims that the humanities 
approach people as "self-aware individuals conscious of their experience [...] reflecting on their lives" (27). For this reason, he views text in its modern expansive sense as the prime object of humanists, and humanity and selfunderstanding as their subject and purpose, respectively (23). He insists on the capacity of texts to increase human self-reflection, which he links with self-governance and accountable democratic citizenship (26). Auden found at least partial relief from his pessimism about established patterns of education through similar ruminations about the humanizing potential of art and the human sciences. His critical writing from the end of the 193os justifies artists, especially writers, as highbrows capable of substituting for education in terms of nurturing humanity and democratic citizenship.

Convinced that education is impractical, over-academic and dictatorial in instilling knowledge, Auden invested considerable energy into persuading his readers that poetry and other forms of writing have an undeniable potential to raise self-knowledge and personal opinion as means of resisting coercion. In 1936 he wrote of such a privileged role thus: "[Art's] power to deepen understanding, to enlarge sympathy, to strengthen the will to action [...] give it an honourable function in any proper community" (1936: 134). It is undoubtedly for this very reason that the number of essays and book reviews which praise writers pointing out such dehumanizing processes and cultivating alertness rose. As early as in 1933, for example, Auden published a positive review of Culture and Environment by F.R. Leavis and Denys Thompson. For Auden, who at the time was teaching in a boarding school, this text was an example of "a practical textbook for assisting children to defeat propaganda of all kinds by making them aware of which buttons are being pressed" (1933b: $\left.3^{8}\right)$.

Auden did not approach writing as a well of knowledge or a source of a doctrine. He rejected the idea of a poet, for instance, as a priest, philosopher or agitator disseminating knowledge or imposing dogma on their readers. Instead, he entrusted poets with an exceptional capacity to elucidate human experience. Poets in his writing became highbrows alert and responsive to life: "one of the motives behind poetry is curiosity, the wish to know what we feel and think" (Auden and Garret 107). Auden held that poets can utilize their ability to use language - "a medium in which all social activities are conducted" - for translating such alertness and experience into an intelligible form (1938b: 469). In other words, poets were not equipped for dictating but for making readers conscious of life and its experience: "They do not invent new thoughts or feelings", Auden asserted in his 1938 Introduction to the poetry 
anthology Poems of Freedom, "but out of their skill with words, they crystallise and define with greater precision thoughts and feelings which are generally present in their class and their age. To adapt the saying of the old lady: 'We know what we think when we see what they say" (1938b: 469). Auden thus conceived of poetry in terms of being the opposite of educational practice and political propaganda. He praised it as a discourse which humanizes by extending human alertness to experience, self-knowledge and awareness of the otherwise imperceptible forces of coercion and critical independence that is necessary for shaping one's opinion. Art for Auden did not become a moralizing tool professing an ethical stance but a means of enlightenment: art "may illuminate", he and Garret wrote in 1935, "but it will not dictate" (108). A heightened capacity for self-reflection and increased awareness, Auden argued, formed an effective shield giving protection against coercion and deception by dictatorial powers. Like Harpham (31), Auden held that art does not improve but that it "reveals" by increasing individuals' self-knowledge and understanding:

[T] he primary function of poetry, as of all arts, is to make us more aware of ourselves and the world around us. I do not know if such increased awareness makes us more moral or more efficient; I hope not. I think it makes us more human, and I am quite certain it makes us more difficult to deceive, which is why, perhaps, all totalitarian theories of the State, from Plato's downwards, have deeply mistrusted the arts. (1938b: 470)

He was convinced that poetry and other art forms provide individuals with the ability to weigh their options and, by extension, assume their own personal stance. The possibility of a rational and responsible choice was for him the most substantial prerequisite of freedom, humanity and democracy, and one which the education system failed to nurture.

Close attention to Auden's prose shows that his opinions on education reflect not only his insight gained through teaching practice, but also his understanding of the idea of democracy and humanity. In his writing Auden repeatedly emphasized the function of education in the social environment. He held that there must be an intimate connection between a given social system and purpose of education. Because he considered democracy to be the polity which suits best the essence of humanity, he argued that education in a democratic country should nurture politically active citizens by means of dwelling on the nurturing of critical awareness and independence, as well as 
the will to participate in social affairs in the expectation that such qualities bring about change and betterment of the social environment. However, such views, in combination with his teaching experience, encouraged his conviction that the established forms of education share a tendency towards the instillment of impractical knowledge, classism and over-specialization, leading to the cultivation of lackadaisical and withdrawn citizens whose lack of critical independence makes them malleable. Auden concluded that education not only fails to cultivate general civic skills but actually participates in the dehumanizing practice through the nurture of manipulatable and passive automatons. Through the decade, as the sustentation of western democracies was increasingly in jeopardy, Auden grew impatient with the educational and political authorities. His despair was partly soothed by an ability to approach arts and the humanities as fields of human activity that nurture humanity. A poet himself, in the course of the 193os Auden repeatedly argued that poetry in particular has the humanizing potential that British education fails to deliver. In his prose and occasionally in verse, he started to champion a view of poetry as a means of nurturing general civic skills and responsible democratic citizens: "What better than your strict and adult pen" Auden wrote in a poem dedicated to the poet Christopher Isherwood in 1935,

Can warn us from the colours and the consolations, /... /

Make action urgent and its nature clear?

Who give us nearer insight to resist

The expanding fear, the savaging disaster? (1988: 157)

Until the end of the decade, Auden was convinced about this very capacity of poetry to crystallize nebulous thoughts and feelings, provide insight and clarify to a point where anyone can make a rational choice, decide independently and act responsibly towards their community as a true democratic citizen.

\section{Notes}

1. Auden's comment also calls to mind T.S. Eliot's 1923 remark on the number of appearances of giraffes in the English novel. See T.S. Eliot, "The Function of Criticism" 33.

2. For the same attitude, see Auden's poem "Oxford" from December 1937.

3. Auden explained this position retrospectively in 1955: "communism was largely a middleclass concern. Looking back, it seems to me that the interest in Marx taken by myself and my friends $[\ldots]$ was more psychological than political; we were interested in Marx 
in the same way that we were interested in Freud, as a technique of unmasking middle class ideologies" (Auden 1955: 524).

4. Auden discusses this issue in detail in "Morality in an Age of Change" (1938d: 477486).

\section{Works Cited}

Almond, Gabriel Abraham and Sidney Verba. The Civic Culture: Political Attitudes and Democracy in Five Nations. Princeton: Princeton University Press, 1966. Print.

Auden, Wystan Hugh. "Writing." 1932. The Complete Works of W.H. Auden, Vol. I.: Prose and Travel Books in Prose and Verse, 1926-1938. Ed. Edward Mendelson. Princeton: Princeton University Press, 1996. 12-24. Print.

--.. "A Review of The Evolution of Sex, by Dr Gregorio Marañón, and The Biological Tragedy of Women, by Anton Nemilov." 1933a. The Complete Works of W.H. Auden, Vol. I.: Prose and Travel Books in Prose and Verse, 1926-1938. Ed. Edward Mendelson. Princeton: Princeton University Press, 1996. 2931. Print.

--.. "A Review of Culture and Environment, by F.R. Leavis and Denys Thompson, and Other Books." 1933b. The Complete Works of W.H. Auden, Vol. I.: Prose and Travel Books in Prose and Verse, 1926-1938. Ed. Edward Mendelson. Princeton: Princeton University Press, 1996. 37-39. Print.

--.. "The Liberal Fascist: Honour." 1934a. The Complete Works of W.H. Auden, Vol. I.: Prose and Travel Books in Prose and Verse, 1926-1938. Ed. Edward Mendelson. Princeton: Princeton University Press, 1996. 55-61. Print.

---. "Life's Old Boy." 1934b. The Complete Works of W.H. Auden, Vol. I.: Prose and Travel Books in Prose and Verse, 1926-1938. Ed. Edward Mendelson. Princeton: Princeton University Press, 1996. 62-66. Print.

---. "Selling the Group Theatre." 1936. The Complete Works of W.H. Auden, Vol. I.: Prose and Travel Books in Prose and Verse, 1926-1938. Ed. Edward Mendelson. Princeton: Princeton University Press, 1996. 134-135. Print.

--.. "Nonsense Poetry" 1938a. The Complete Works of W.H. Auden, Vol. I.: Prose and Travel Books in Prose and Verse, 1926-1938. Ed. Edward Mendelson. Princeton: Princeton University Press, 1996. 467-468. Print.

--.. "Introduction to Poems of Freedom, edited by John Mulgan." 1938b. The Complete Works of W.H. Auden, Vol. I.: Prose and Travel Books in Prose and Verse, 1926-1938. Ed. Edward Mendelson. Princeton: Princeton University Press, 1996. 469-470. Print.

---. "The Teaching of English." 1938c. The Complete Works of W.H. Auden, Vol. I.: 
Prose and Travel Books in Prose and Verse, 1926-1938. Ed. Edward Mendelson. Princeton: Princeton University Press, 1996. 475-477. Print.

---. "Morality in an Age of Change." 1938d. The Complete Works of W.H. Auden, Vol. I.: Prose and Travel Books in Prose and Verse, 1926-1938. Ed. Edward Mendelson. Princeton: Princeton University Press, 1996. 477-486. Print.

---. "Foreword to Poet Venturers: A Collection of Poems Written by Bristol School Boys and Girls." 1938e. The Complete Works of W.H. Auden, Vol. I.: Prose and Travel Books in Prose and Verse, 1926-1938. Ed. Edward Mendelson. Princeton: Princeton University Press, 1996. 471. Print.

---. The Prolific and the Devourer. 1939a. The Complete Works of W.H. Auden. Vol. II.: Prose, 1939-1948. Ed. Edward Mendelson. London: Faber and Faber, 2002. 411-458. Print.

--. "Democracy's Reply to the Challenge of Dictators." 1939b. The Complete Works of W.H. Auden, Vol. I.: Prose and Travel Books in Prose and Verse, 19261938. Ed. Edward Mendelson. Princeton: Princeton University Press, 1996. 463-466. Print.

---. "Vocation and Society." 1943. The Complete Works of W.H. Auden. Vol. II.: Prose, 1939-1948. Ed. Edward Mendelson. London: Faber and Faber, 2002.175-183. Print.

---. "Introduction to Slick but Not Streamlined, by John Betjeman." 1947. The Complete Works of W.H. Auden. Vol. II.: Prose, 1939-1948. Ed. Edward Mendelson. London: Faber and Faber, 2002. 303-307. Print.

--.. "Authority in America." 1955. The Complete Works of W.H. Auden. Vol. III.: Prose, 1949-1955. Ed. Edward Mendelson. Princeton: Princeton University Press, 2008. 521-527. Print.

---. The Enchafèd Flood: Or the Romantic Iconography of the Sea. New York: Random House, 1967. Print.

---. Collected Poems. Ed. Edward Mendelson. 1st trade ed. New York: Random House, 1976. Print.

---. The English Auden: Poems, Essays and Dramatic Writings, 1927-1939. Ed. Edward Mendelson. London: Faber and Faber, 1988. Print.

Auden, Wystan Hugh and John Garret. "Introduction to The Poet's Tongue." 1935. The Complete Works of W.H. Auden, Vol. I.: Prose and Travel Books in Prose and Verse, 1926-1938. Ed. Edward Mendelson. Princeton: Princeton University Press, 1996. 105-109. Print.

Auden, Wystan Hugh and T.C. Worsley. "Education." 1937. The Complete Works of W.H. Auden, Vol. I.: Prose and Travel Books in Prose and Verse, 1926-1938. 
Ed. Edward Mendelson. Princeton: Princeton University Press, 1996. 389-424. Print.

Cunningham, Valentine. British Writers of the Thirties. Oxford: Oxford University Press, 1988. Print.

Eliot, T.S., "The Function of Criticism." T.S. Eliot: Selected Essays. London: Faber and Faber Ltd, 1932. 23-34. Print.

Harpham, Geoffrey Galt. "Beneath and beyond the 'Crisis in the Humanities."' New Literary History, vol. 36, no. 1, 2005, 21-36. Web. www.jstor.org/ stable/20057872. Accessed 13 February 2017.

Mendelson, Edward. Preface. The English Auden: Poems, Essays and Dramatic Writings, 1927-1939, by Wystan Hugh Auden. Ed. Edward Mendelson. London: Faber and Faber, 1988 [1977]. xiii-xxiii. Print.

Mitchison, Naomi. You May Well Ask: A Memoir 1920-1940. London: Victor Gollancz Ltd., 1979. Print.

LADISLAV VÍT is an Assistant Professor at the Department of English and American Studies, University of Pardubice, Czech Republic. In 2013, he received his $\mathrm{PhD}$ in English and American Studies at Charles University, Prague, Czech Republic. His dissertation, Topophilia and Escapism: W.H. Auden's Interwar Poetics of Place (1927-1938), deals with the poetics of place in the early poetry of W.H. Auden. Specializing in British literature and culture, Ladislav Vít's research interests are landscape architecture, literary representation of space, topographical writing, British interwar literature and W.H. Auden's poetry and prose. He has published articles on W.H. Auden, the poetics of place and travel writing. He is also one of the founding members and an Executive Editor of the academic journal American and British Studies Annual (Scopus, Erih). Ladislav Vít also co-organizes the international Cultural Studies conference In/Out of Frame.

\section{Ladislav.Vit@upce.cz}

